\title{
Nutrient Composition and Sensory Evaluation of Three Selected Local Dishes Consumed in Ipokia Local Government Area of Ogun State, Nigeria
}

\author{
Quadri J. A.*, Ojure M. A., Edun B. T. \\ Department of Nutrition and Dietetics, Ogun State College of Health Technology, Ilese- Ijebu, Ogun State, Nigeria \\ Email address: \\ olaquadri2004@yahoo.co.uk (Quadri J. A.) \\ ${ }^{*}$ Corresponding author \\ To cite this article: \\ Quadri J. A., Ojure M. A., Edun B. T. Nutrient Composition and Sensory Evaluation of Three Selected Local Dishes Consumed in Ipokia \\ Local Government Area of Ogun State, Nigeria. International Journal of Nutrition and Food Sciences. Vol. 6, No. 4, 2017, pp. 175-180. \\ doi: 10.11648/j.ijnfs.20170604.15
}

Received: June 12, 2016; Accepted: June 22, 2016; Published: July 12, 2017

\begin{abstract}
The study was carried out to determine the nutrient composition and sensory evaluation of three selected local dishes in Ipokia local government area of Ogun state, Nigeria. The recipe of the three dishes was collected from the study area. The ingredients for the dishes were standardized and later the nutrient composition was determined using AOAC (2001) and also sensory evaluation carried on the dishes. The result shows that by simple comparison, Tutu contained more water, followed by the Atomboro then Ata Paki which is fried and therefore contained less moist (mean=99.19, 97.97, and 97.67). However, the fat content of the Ata Paki was more than Atomboro and Tutu but Atomboro also contain more fat as compared Tutu (mean= 2.04, 1.49 and 0.72), there are more protein in Atomboro, then tutu and Ata Paki, this is possible because of beans content of the dishes. Generally in term of vitamins contents of the dishes, 'Ata Paki' contained more vitamins than the other dishes. Though, Atomboro has more vitamins than Tutu. However, there is more vitamin A in Atomboro (0.0975) and Ata Paki (0.0534) whiles more Vitamin $\mathrm{B}_{2}$ in Tutu (0.0744). For the sensory evaluation, the taste, appearance and overall acceptability for "atomboro" was rated 75, 65 and 85 percent while "tutu" rated 60, 80 and 65 percent and "ata-paki" rated 70 , 70,60 percent respectively which shows that "atomboro" is more acceptable as compared to other dishes. The results of the analysis indicated that, despite the acceptability of the dishes, there is insignificant amount of some nutrients that are essential for human health and maintenance. The study concluded that with some nutrients/constituents that are insignificant in the dishes, there is need to improve the dishes by including or improving sources of protein, minerals and fibre like fishes and meats and fruits as an accompaniment with the dishes.
\end{abstract}

Keywords: Nutrient Composition, Sensory Evaluation, Standardization

\section{Introduction}

Traditional foods are foods that were consumed throughout history before the modernization and industrialization of the food supply [1]. These foods are not only free from additives, chemicals and many of the things we find in food today, but they were exceptionally nourishing [2]. Though, the specifics of traditional food varied by culture.

Local foods can be enjoyed by people but the recipes might not be standardized, which can affect the quality of the food and the consumer might not derived maximum benefit. Poor dietary choices can lead to a host of conditions related to malnutrition, which include a weakened immune system as well as long-term chronic health challenges. Therefore, there is need to standardize the recipes of food consumed by people, evaluate the sensory and nutritional composition of these food in order to maximize the benefit of these food for health of individual.

Globally, some of the examples of these traditional food are healthy proteins like free range meats, fish or eggs, beneficial fats from healthy sources including coconut based fats, handmade butter, tallow, lard, ghee and olive oil, fermented foods, bone broth or soups cooked with bone-in meat for the variety of minerals and gelatine, organ meats, 
vegetables, fruits and nuts, especially leafy greens, sometimes tubers and root vegetables and raw dairy and dairy products (in some cultures) like fura and nunu among the Fulani tribes in Nigeria [3].

Most of the modern dishes today contain chemical addictives that are injurious to the health of consumers and they need to be avoided. Some studies have shown that chemical additives in food consumed by people are dangerous [4]. The frightening thing about chemical additives is that their effects are not always immediately seen. Very often their effects are cumulative, meaning that the body experiences a gradual accumulation that could lead to a variety of symptoms [5].

Chronic poor nutrition is a risk factor for a wide range of diseases including osteoporosis, diabetes, and obesity [6]. However, the nutritional value of food is not primarily what makes people to eat. It might be colour, flavour, texture, temperature and presentation and above all the culture and traditions of people might influence the choice of foods. Based on the aforementioned, the present study was undertaken to assess the recipes Standardization, Sensory Evaluation and nutritional Composition of three selected local dishes consumed in Ipokia local government area of Ogun State Nigeria.

The Objectives of the study is to:

- collect the recipes of the three dishes and standardize it

- carry out sensory evaluation on the standardized dishes

- determine the proximate composition of the dishes standardized

The study focused on three popular local foods in Ipokia local government area with selected chemical properties determine on them.

\section{Materials and Methods}

The study involved both survey and laboratory work. The laboratory work includes the acquiring and selection of raw materials for the various dishes from the market. Then, the dishes were prepared under Laboratory conditions measuring the ingredients; apply necessary conditions and procedures for determination of chemical composition. The second part of the study was survey among the people for the sensory evaluation of the dishes.

\subsection{Procedure for Sensory Evaluation of the Dishes}

When the quality of food products is assessed by means of human sensory organs, the evaluation is said to be sensory or subjective or organoleptic. The evaluation involved both staff and students from different culture and background. Acceptability and organoleptic scoring of the preparations was done on the basis of the scores given by the evaluators. The recipes was evaluated for the following using the method of Gorny, et al, [7].
1). Appearance
2). Texture
3). Taste
4). Flavour,
5). Aroma

6). Mouth Feel

7). Odour

8). Overall acceptability.

The score card for assuring the quality of the product was developed according to Hopkins's eleven point scale was modified to a nine point scale cited in Gaggat, et. al. [8]. A copy of score card was given to each evaluator. Then comparison was done for evaluation for the parameters above which was based on the following hedonic scale: $9=$ excellent, most acceptable; 7-8 = very good, acceptable; 5-6 $=$ fair, limited acceptability; 1-4 = non acceptable. The scale was adapted from Gornyet al., [7].

\subsection{Procedure for Determination of Chemical Composition of the Dishes}

Proximate analysis using AOAC [8] was carried out to determine the nutritive values of the three dishes. These three dishes were analyzed for the following parameters:
1). Moisture
2). Protein
3). Fat
4). Ash
5). Crude fibre

The proximate analysis adopted using the method of AOAC [8], has been a technique widely used because they offer good information about sample composition. Their principal advantages are separation efficiency; identification of almost any type of molecule present in a food sample.

The data collected were analyzed by representation and comparison of the results from each dish with descriptive statistical tools of table, percentiles, and chartsto compare the results obtained.

\section{Results and Discussion}

\subsection{Demographics Characteristics of the Subjects}

The following table and figures below contained the demographics characteristics of the twenty (20) subjects who took part in the sensory evaluation of the three dishes.

Table 1. Demographics Characteristics of the Subjects.

\begin{tabular}{lll}
\hline Variable & Frequency & Percentage \\
\hline SEX & 6 & 30 \\
Male & 14 & 70 \\
Female & & \\
AGE (Years) & 14 & 70 \\
$18-25$ & 5 & 25 \\
$26-35$ & 1 & 5 \\
$36-50$ & 19 & \\
Tribe & 1 & 95 \\
Yoruba & 15 & 5 \\
Igbo & 5 & \\
Religious Affiliations of the subjects & 75 \\
Christianity & 12 & 25 \\
Islam & 8 & \\
Marital Status Distribution of the subjects & 60 \\
Single & 0 & 40 \\
Married & & 0 \\
Divorced &
\end{tabular}


The total number of male subjects that took part in the sensory evaluation was $6(30 \%)$ while the females were 14 $(70 \%)$. As shown on the Table 1 , the age distribution of the subjects showed that fourteen (14) of them are in the age bracket of 18-25, five (5) are between ages of 26-35 and only one (1) in the age bracket of 36-50.

However, Nineteen (19) of the respondents are from Yoruba tribe. One Igbo took part, but neither Hausa nor Egun tribe was involved in the evaluation.

The religious affiliations of the subjects are Christianity and Islam, there is no traditionalists among the subjects. Fifteen Christians (15) took part in the evaluation while the rest five (5) are Muslims. The responses on the marital status showed that twelve (12) of the subjects are single while the rest eight (8) are married.

Table 2. Recipes Standardization of the dishes.

\begin{tabular}{lllll}
\hline S/N & Ingredients & $\begin{array}{l}\text { Mean } \\
\text { ('Atomboro') }\end{array}$ & $\begin{array}{l}\text { Mean } \\
\text { ('Tutu') }\end{array}$ & $\begin{array}{l}\text { Mean } \\
\text { ('Atapaki') }\end{array}$ \\
\hline 1. & Beans (g) & 1842.5 & 2021.3 & \\
2. & Onion (g) & 155 & 135.7 & 115 \\
3. & Pepper (teaspoon) & 6 & 8 & 2 \\
4. & Palm oil (ml) & 350 & 337.5 & 300 \\
5. & Maggi (cube) & 2.5 & 2 & \\
6. & Salt (teaspoon) & 2 & 2.5 & 2 \\
7. & Corn powder (g) & - & 138.8 & \\
8. & Cassava (kg) & - & - & 5.4 \\
9. & Groundnut oil (ml) & - & - & 585 \\
10. & Sugar (g) & - & - & 20 \\
\hline
\end{tabular}

There are five (5) basic ingredients needed for preparation of Atomboro. They are Beans, Onion, Pepper, Palm Oil, salt and Maggi. Beans are the major ingredient, then palm oil and Onion. However, the means values of recipe standardizations obtained from ten respondents from the study area are as follows: $1842.5 \mathrm{~g}$ of Beans, $155 \mathrm{~g}$ of Onion, 6 teaspoon of pepper, $350 \mathrm{ml}$ of palm oil and 2.5 cubes of Maggi.

However, there are seven (7) basic ingredients needed for preparation of Tutu. The ingredients are similar with that of Atomboro which inclusion of Corn Powder. Therefore the ingredients are Corn powder, Beans, Onion, Salt, Pepper, Palm Oil and Maggi. For Tutu, beans are also the major ingredient. The means values of recipe standardizations obtained from ten respondents from the study area are as follows: $138.75 \mathrm{~g}$ of corn powder, $2021.25 \mathrm{~g}$ of Beans, 337.5 $\mathrm{ml}$ of palm oil $137.5 \mathrm{~g}$ of Onion, $81.25 \mathrm{~g}$ of added salt, 8 teaspoon of pepper, and 2.2 cubes of Maggi.

There are six (6) basic ingredients needed for preparation of Ata Paki but different major ingredients are been used. However, the ingredients are cassava, salt, onion, pepper, and sugar; some make use of groundnut oil others uses palm oil. The means values of recipe standardizations obtained from ten respondents from the study area are as follows: $5.4 \mathrm{~kg}$ (5400g) of cassava, $25 \mathrm{~g}$ of salt, $115 \mathrm{~g}$ of Onion, 2 teaspoons of pepper, $20 \mathrm{~g}$ of sugar while $300 \mathrm{ml}$ of palm oil otherwise groundnut oil can be used with $585 \mathrm{ml}$ volume.
Table 3. Proximate Analysis of the Samples.

\begin{tabular}{llll}
\hline SAMPLES (\%) & $\begin{array}{l}\text { MOISTURE } \\
\text { CONTENT }\end{array}$ & FAT & $\begin{array}{l}\text { CRUDE } \\
\text { PROTEIN }\end{array}$ \\
\hline \multirow{2}{*}{ Atomboro $\left(\mathrm{F}_{1}\right)$} & 97.98 & 1.61 & 0.008 \\
& 97.96 & 1.21 & 0.009 \\
Mean & 97.68 & 1.66 & 0.01 \\
& 97.87 & 1.49 & 0.009 \\
(Tutu) $\mathrm{F}_{2}$ & 99.12 & 0.71 & 0.003 \\
& 99.19 & 0.74 & 0.004 \\
Mean & 99.26 & 0.7 & 0.008 \\
& 99.19 & 0.72 & 0.005 \\
(Ata Paki) $\mathrm{F}_{3}$ & 97.85 & 2.03 & 0.004 \\
& 97.42 & 2.09 & 0.005 \\
Mean & 97.81 & 2 & 0.004 \\
\hline
\end{tabular}

\subsection{Mean are from the Samples in Triplicate}

The results of the proximate analysis for the three dishes were shown on table 3. The figures indicated that the Moisture Contents analysed in "Atomboro", Tutu and Ata Paki was 97.97, 99.19 and 97.67 respectively. Then, fat contents in Atomboro, "Tutu" and Ata Paki was 1.49, 0.72 and 2.04 respectively while crude protein detected in the three dishes were 0.009 in Atomboro, 0.005 in Tutu and 0.004 in Ata Paki. Though, the results showed that Tutu dish contained more moisture content than the two, followed by Atomboro then Ata Paki. But there are more fat contents in Ata Paki than the rest two dishes while Atomboro contained more fat than the Tutu. Furthermore, the crude contents are rather low compared with other constituents detected with Atomboro containing 0.009, Tutu (0.005) and Ata Paki (0.004).

By simple comparison, Tutu contained more water, followed by the Atomboro then Ata Paki which is fried and therefore contained less moist. However, the fat content of the Ata Paki was more than Atomboro and Tutu but Atomboro also contain more fat as compared Tutu, there are more protein in Atomboro, then tutu and Ata Paki, this is possible because of beans content of the dishes.

Table 4. Vitamin content of the dishes.

\begin{tabular}{lllll}
\hline \multirow{2}{*}{ SAMPLES } & $\begin{array}{l}\text { VITAMIN } \\
\mathbf{A} \boldsymbol{\mu g} / \mathbf{g}\end{array}$ & $\begin{array}{l}\text { Vitamin } \mathbf{B}_{\mathbf{1}} \\
\mathbf{m g} / \mathbf{1 0 0} \boldsymbol{\mu}\end{array}$ & $\begin{array}{l}\text { Vitamin } \\
\mathbf{m g} / \mathbf{1 0 0} \boldsymbol{\mu}\end{array}$ & $\begin{array}{l}\text { VITAMIN } \\
\mathbf{C} \mathbf{~ m g} / \mathbf{1 0 0} \boldsymbol{\mu}\end{array}$ \\
\hline \multirow{2}{*}{$\mathrm{F}_{1}$} & 0.0857 & 0.0449 & 0.0428 & 0.114 \\
(Atomboro) & 0.1143 & 0.0445 & 0.0446 & 0.123 \\
Mean & 0.0926 & 0.0461 & 0.0445 & 0.12 \\
& 0.0975 & 0.0452 & 0.0439 & 0.119 \\
$\mathrm{~F}_{2}$ (Tutu) & 0.3223 & 0.0891 & 0.0751 & 0.012 \\
& 0.2871 & 0.0899 & 0.0725 & 0.012 \\
Mean & 0.2991 & 0.0899 & 0.0756 & 0.045 \\
& 0.3028 & 0.0896 & 0.0744 & 0.041 \\
F $_{3}$ (Ata Paki) & 0.0544 & 0.0611 & 0.0581 & 0.068 \\
& 0.0544 & 0.0628 & 0.0588 & 0.069 \\
Mean & 0.0513 & 0.0621 & 0.0519 & 0.086 \\
\hline
\end{tabular}

The results of the vitamin analysis for the three dishes were shown on the table 4. Four different types of Vitamin were analysed in the samples: Vitamin A, $B_{1}, B_{2}$ and Vitamin $C$. The valueson table 4 indicated that mean values of the vitamins. In Atomboro, the vitamins values were 0.0975 of 
Vitamin A, 0.0452 of Vitamin $B_{1}, 0.0439$ of Vitamin $B_{2}$ and 0.119 of VitaminC $\mathrm{mg} / 100 \mu$. For Tutu, the vitamins were $0.3028 \mu \mathrm{g} / \mathrm{g}$ of Vitamin $\mathrm{A}, 0.0896$ of $\mathrm{B}_{1}, 0.0744$ of $\mathrm{B}_{2}$ and 0.041 of VitaminC $\mathrm{mg} / 100 \mu$. Then for Ata Paki, the values for Vitamins analysed were $0.0534 \mu \mathrm{g} / \mathrm{g}$ of Vitamin A, 0.0621 of Vitamin $B_{1}, 0.0563$ of Vitamin $B_{2}$ and 0.074 of
VitaminC mg/100 $\mu$.

Generally in term of vitamins contents of the dishes, 'Ata Paki' contained more vitamins than the other dishes 'Atomboro and Tutu'. Though, Atomboro has more vitamins than Tutu. However, there is more vitamin A in Atomboro and Ata Paki while more Vitamin $\mathrm{B}_{2}$ in Tutu.

Table 5. Sensory Evaluation for "Atomboro" Dish.

\begin{tabular}{lllll}
\hline & Non Acceptable (\%) & Fair or Limited acceptability (\%) & Very Good or acceptable (\%) & $\begin{array}{l}\text { Excellent or most acceptable } \\
(\%)\end{array}$ \\
\hline Apperance & - & & 25 & 75 \\
Texture & - & - & 45 & 55 \\
Taste & - & - & 15 & 85 \\
Flavour & - & - & 50 & 50 \\
Aroma & - & - & 30 & 70 \\
Mouth Feel & - & - & 30 & 70 \\
Odour & - & - & 50 & 50 \\
Overall accept. & - & - & 35 & 65 \\
\hline
\end{tabular}

The acceptability test carried on 'Atomboro' shows that the food was well accepted based on the parameters used. The result showed that $25 \%$ of the panelist rated the appearance to be very good while $75 \%$ rated excellent and the texture was rated $45 \%$ very good while $55 \%$ excellent. Another $85 \%, 50 \%, 70 \%, 50 \%$ and $65 \%$ rated the taste, flavor, aroma, mouth feel, odour and overall acceptability of atomboro to be excellent respectively.

Table 6. Sensory Evaluation for “Tutu” Dish.

\begin{tabular}{|c|c|c|c|c|}
\hline & Non Acceptable (\%) & Fair or Limited acceptability (\%) & Very Good or acceptable (\%) & $\begin{array}{l}\text { Excellent or most } \\
\text { acceptable }(\%)\end{array}$ \\
\hline Appearance & - & - & 20 & 80 \\
\hline Texture & - & - & 40 & 60 \\
\hline Taste & - & - & 25 & 75 \\
\hline Flavour & - & - & 25 & 75 \\
\hline Aroma & - & - & 20 & 80 \\
\hline Mouth feel & - & - & 25 & 75 \\
\hline Overall accept. & - & - & 35 & 65 \\
\hline
\end{tabular}

The acceptability test carried on 'Tutu' shows that the food was well accepted based on the parameters used. The result showed that $20 \%$ of the panelist rated the appearance to be very good while $80 \%$ rated excellent and the texture was rated $40 \%$ very good while $60 \%$ excellent. Another $75 \%, 80 \%, 75 \%, 80 \%$ and $65 \%$ rated the taste, flavor, aroma, mouth feel, odour and overall acceptability of Tutu to be excellent respectively.

Table 7. Sensory Evaluation for “Ata Paki” Dish.

\begin{tabular}{lllll}
\hline & Non Acceptable (\%) & Fair or Limited acceptability (\%) & Very Good or acceptable (\%) & $\begin{array}{l}\text { Excellent or most acceptable } \\
(\%)\end{array}$ \\
\hline Appearance & - & - & 30 & 70 \\
Texture & - & - & 45 & 55 \\
Taste & - & - & 30 & 70 \\
Flavour & - & - & 35 & 65 \\
Aroma & - & - & 30 & 70 \\
Mouth feel & - & - & 30 & 65 \\
Odour & - & - & 35 & 60 \\
Overall accept. & - & - & 40 & 60 \\
\hline
\end{tabular}

The acceptability test carried on 'Ata paki' shows that the food was well accepted based on the parameters used. The result showed that $30 \%$ of the panelist rated the appearance to be very good while $70 \%$ rated excellent and the texture was rated $45 \%$ very good while $55 \%$ excellent. Another $70 \%$, $65 \%, 70 \%, 70 \%, 65 \%$ and $60 \%$ rated the taste, flavor, aroma, mouth feel, odour and overall acceptability of Ata paki to be excellent respectively.

Similarly, none of the subjects reject the Ata paki dish out rightly based on the variables of appearance, texture, taste, flavour, aroma, mouth feel, and odour but the overall acceptability of the dish was less than that of the Atomboro and Tutu which was sixty percent $(60 \%)$.

\section{Discussion}

The study was carried out on recipe standardization, sensory evaluation and chemical composition of the three 
local dishes "Atomboro, Tutu and Ata Paki" consumed in Ipokia Local Government Area.

The eating traditions of every country and culture are the result of millennia of history. Geographical location and climatic conditions play a predominant role in growing, harvesting and availability of food products influencing the food habits of the ethnic populations [9]. The methods of food preparation are diverse and her related to the types of available food [10] and that informed the recipe standardization carried out, to determine the reference standard that can be used in preparing the foods, so far that food is represented as part of the cultural traits of an ethnic community. The cultural background determines what shall be eaten as well as when and how it shall be eaten [11].

The overall results, generally on the sensory evaluations showed that the three dishes were widely accepted by people, the acceptability might be as a result of the ingredients the dishes contained like Beans, corns that have been the major and common staple food consumed by the people and the results obtained from the acceptability test is supported by the work of Mojekwu and Anyafulu [12] on the acceptability of nutritional composition and sensory analysis of local dishes and theother carried out in Tanzania by Muhimbula, et. al., [13] that worked on formulation and sensory evaluation of complementary foods from local, cheap and readily available cereals and legumes in Iringa, Tanzania. The results showed that those dishes with beans and palm oil as ingredients have fat and protein contents that the human body required.

On the other hand, the proximate analysis indicated that the dishes contained moisture contents that can aid digestion, fat that maintain skin integrity and also a considerable amount of protein that helps in repairing and building body tissue.

Furthermore, the results of the vitamin analysis indicated that detection of the vitamins $\mathrm{A}, \mathrm{B}_{1}, \mathrm{~B}_{2}$ and $\mathrm{C}$ showed that the dishes can give the consumers those highlighted vitamins and they are very important to human health. For instance Vitamin A for vision and boosting of immune system should have been derived from palm oil and onions, all the $\mathrm{B}$ Vitamins help the body convert food (carbohydrates) into fuel (glucose), which is used to produce energy. These B vitamins, often referred to as B complex vitamins, also help the body metabolize fats and protein [14]. B complex vitamins are needed for healthy skin, hair, eyes, and liver andalso help the nervous system function properly, and are needed for good brain function [14]. Though, it was only Vitamin $B_{1}$ and $B_{2}$ analysed in all the three dishes and their sources are beans, corns and salt. While, Vitamin $\mathrm{C}$ was also analysed in all the three dishes, but Ata Paki and Tutu have the highest amount of vitamin $\mathrm{C}$ which is an anti-oxidant that fight against infection and foreign bodies that get into human bodies and onion as one of the ingredients was also the source of the vitamin.

\section{Conclusion}

The results of the analysis indicated that, despite the acceptability of the dishes, there is insignificant amount of some nutrients that are essential for human health and maintenance. The study concluded that with some nutrients/constituents that are insignificant in the dishes, there is need to improve the dishes by including or improving sources of protein, minerals and fibre like fishes and meats and fruits as an accompaniment with the dishes.

\section{Recommendations}

- It is recommended that the three dishes (Atomboro, Tutu and Ata-paki) should be consumed by the populace due to the result of analysis that confirmed the presence of protein which is good for the building and repairing of worn out tissues in the body, fat which assists in proper functioning of skin cells and also serves as transporter of fat soluble vitamins, moisture which aid in the proper digestion of food, vitamin A which is essential for normal vision and functioning of the immune system, B complex vitamins which are needed for proper functioning of the nervous system and metabolism of fat and carbohydrate and lastly vitamins $\mathrm{C}$ which serves as antioxidant that helps in fighting against infections and foreign bodies that gets into human bodies.

- It is also recommended that there is need for further studies by using unpeeled beans for Atomboro so as to enrich the protein and fibre content to make it moreadequate in term of nutrients needed for human survival.

\section{References}

[1] Fellows, P. P, (1997) 'Traditional Foods, Intermediate Technology Publications, UK.

[2] Sharma, S., Cao, X., Gittelsohn, J., Ethelbah, B. and Anliker, J. (2008) 'Nutritional composition of commonly consumed traditional Apache foods in Arizona', International Journal of Food Sciences and Nutrition, 59 (1), pp. 1-10.

[3] Achinewhu, S. C, Ogbonna C. C, Hart, A. D. (1995), 'Chemical composition of indigenous wild herbs, spices, fruits, nuts and leafy vegetables used as food', Plant Foods Hum Nutr., Vol 48, Pp. 341-348.

[4] Andrade, P. D., de Mello, H. M., França, J. A., \& Caldas, E. D. (2013). Aflatoxins in food products consumed in Brazil: a preliminary dietary risk assessment. Food Additives \& Contaminants: Part A, 30 (1), 127-136.

[5] Hartley, J., (2008). Chemical Additives and Their Effects on Children. Natural News Network Safe food, (2014); Nutrition and Healthy Eating.

http://www.safefood.eu/Professional/Research/Nutrition.aspx.

[6] Gorny, R. J., Cifuentes, A. R. Hess-Pierce, B. and Kader, A. A. (2000). Quality changes in fresh cut pear slices as affected by cultivar, ripeness stage, fruit size and storage regime. J. Food Sci., 65: 541-544. 
[7] Gaggat, P, Sethi, N and Singh, K. (2014) 'Standardisation, Organoleptic Evaluation and Biochemical Evaluation of Recipes Using Oats and Flax Seed. International Journal of Food And Nutritional Science' Vol. 3, Iss. 1.

[8] AOAC (2000): Official Methods of Analysis. 17th ed. Association of Official Analytical Chemists International. Washington, DC, USA.

[9] Finn, A and Louviere, J. J (1992). Determining the approporiate response to evidence of public concern: the case of food safety. Journal of Public policy and marketing. 11 (1), Pp 12-25.

[10] Fieldhouse P. (1995); Food and Nutrition: Customs and Culture. London: Chapman and Hall.

[11] Bhatia, B. M (1985). Food security in South Asia. New Delhi: Oxford \& IBH Publishing Co.
[12] Mojekwu C. C and Anyafulu A. M (2014) Analysis of Nutritional Composition and Acceptability of Selected Fast Foods and Standardized Indigenous Dishes in Nigeria Research Journal in Organizational Psychology \& Educational Studies 3 (6) 415-418.

[13] Muhimbula, H. S., Issa-Zacharia, A., \& Kinabo, J. (2010). Formulation and sensory evaluation of complementary foods from local, cheap and readily available cereals and legumes in Iringa, Tanzania. African Journal of Food Science. 5 (1) pp 26-31.

[14] Ojofeitimi, E. O. (2009); Vitamins and minerals in principles and practice of nutrition for public health practitioners. Nonesuchhouse Publishers, Ibadan, Nigeria, pp 32-49. 